ISA

Arboriculture \& Urban Forestry 2017. 43(6):242-256

\title{
Chlorantraniliprole: Reduced-risk Insecticide for Controlling Insect Pests of Woody Ornamentals with Low Hazard to Bees
}

\author{
Carl T. Redmond and Daniel A. Potter
}

\begin{abstract}
Landscape professionals need target-selective insecticides for managing insect pests on flowering woody ornamentals that may be visited by bees and other insect pollinators. Chlorantraniliprole, the first anthranilic diamide insecticide registered for use in urban landscapes, selectively targets the receptors that regulate the flow of calcium to control muscle contraction in caterpillars, plant-feeding beetles, and certain other phytophagous insects. Designated a reducedrisk pesticide by the United States Environmental Protection Agency, it has a favorable toxicological and environmental profile, including very low toxicity to bees and most types of predatory and parasitic insects that contribute to pest suppression. Chlorantraniliprole has become a mainstay for managing turfgrass pests, but little has been published concerning its performance against the pests of woody ornamentals. Researchers evaluated it against pests spanning five different orders: adult Japanese beetles, evergreen bagworm, eastern tent caterpillar, bristly roseslug sawfly, hawthorn lace bug, oleander aphid, boxwood psyllid, oak lecanium scale (crawlers), and boxwood leafminer, using real-world exposure scenarios. Chlorantraniliprole's efficacy, speed of control, and residual activity as a foliar spray for the leaf-chewing pests was as good, or better, than provided by industry standards, but sprays were ineffective against the sucking pests (lace bugs, aphids, or scales). Basal soil drenches in autumn or spring failed to systemically control boxwood psyllids or leafminers, but autumn drenches did suppress roseslug damage and Japanese beetle feeding the following year. This study indicates that chlorantraniliprole can be an effective component of integrated pest and pollinator management programs on woody ornamentals.

Key Words. Anthranilic Diamide; Bees; Boxwood Leafminer; Boxwood Psyllid; Bristly Roseslug; Chlorantraniliprole; Eastern Tent Caterpillar; Evergreen Bagworm; Hawthorn Lace Bug; Japanese Beetle; Oak Lecanium Scale; Oleander Aphid; Pollinators.
\end{abstract}

Bees and other insect pollinators face growing threats from the spread of exotic parasites and pathogens, loss of nesting habitat and floral resources (pollen and nectar), intensified land use, including use of pesticides, and other factors (Kearns et al. 1998; Goulson et al. 2007; Potts et al. 2010; Goulson et al. 2015). Land care professionals are increasingly expected to incorporate best management practices for safeguarding bees when controlling pests of woody ornamentals and turf (Larson et al. 2014; Smitley et al. 2016). Failure to do so can result in bee kills, negative publicity, fines or license suspension, and calls for further restrictions on insecticides, whereas "bee-friendly" land care reflects positively on the industry.
Most of the synthetic insecticides currently used in urban landscapes are toxic to bees if sufficient dosage and exposure levels are met (Besard et al. 2011; Hooven et al. 2013; Tomé et al. 2015; Zhu et al. 2015). Neonicotinoids, especially imidacloprid, dinotefuran, clothianidin, and thiamethoxam, are under scientific and regulatory scrutiny because of their potential to translocate to pollen and nectar (Blacquière et al. 2012; Goulson 2013; Godfray et al. 2014; Bonmatin et al. 2015; Pisa et al. 2015). Pyrethroids, too, may have both acute and sub-lethal adverse effects on bee health (Inglesfield 1989; Oliver et al. 2015).

Landscape professionals need target-selective insecticides for managing insect pests on plants that may be visited by bees. Anthranilic diamides 
are among the most promising alternatives to neonicotinoids and pyrethroids for that purpose. This relatively new class of synthetic insecticides targets the ryanodine receptors (RyRs), which regulate the flow of calcium to control muscle contraction. Anthranilic diamides bind to RyRs, causing them to remain open, depleting calcium ions and leading to rapid cessation of feeding (Hannig et al. 2009), muscle paralysis, and death. The primary route of exposure is through ingestion (Lahm et al. 2007; Yu 2015).

Chlorantraniliprole (Acelepryn ${ }^{\circ}$; Syngenta, Greensboro, North Carolina, U.S.) is the first anthranilic diamide registered for use on turfgrass and landscape ornamentals. Designated a reduced-risk pesticide by the United States Environmental Protection Agency (US-EPA 2008), it has a favorable toxicological and environmental profile and requires no signal word on its label. Chlorantraniliprole selectively targets the RyRs in muscle fibers of caterpillars (Lepidoptera) and some species in the orders Coleoptera, Hymenoptera, Diptera, and Hemiptera (Cordova et al. 2006; Lahm et al. 2007). Differential RyR sensitivity is why chlorantraniliprole is more active against some types of insects than others (Isaacs et al. 2012; Wang et al. 2012; Qi and Casida 2013), and is the reason for its low toxicity to bees (Dinter et al. 2008a; Gradish et al. 2010; Larson et al. 2013; Qi and Casida 2013; Zhu et al. 2015) and to most families of predatory and parasitic insects that contribute to biological control (Brugger et al. 2009; Gradish et al. 2011; Larson et al. 2012; Larson et al. 2014; Whalen et al. 2016). Chlorantraniliprole is essentially non-toxic to mammals, birds, and fish because vertebrate RyRs are 400 to 3000 times less sensitive to it than are RyRs of susceptible insects (Cordova et al. 2006; Wang et al. 2012).

Chlorantraniliprole has been widely evaluated for management of turfgrass pests, especially scarab grubs and caterpillars, and since its commercial launch in 2008 it has become an industry mainstay for that purpose (Held and Potter 2012). In comparison, there is little published information concerning its performance against pests of woody ornamentals in landscape settings, which may account for why it seems to be relatively undiscovered by tree care professionals.
This paper presents results from a series of trials that evaluated the performance of chlorantraniliprole against selected pests of ornamental trees and shrubs in real-world scenarios. Researchers also summarize current knowledge concerning its efficacy against additional landscape pests, and identify pests and usage scenarios for which additional information is needed.

\section{METHODS AND MATERIALS}

Trials were conducted between 2010 and 2016, targeting nine pests of ornamental plants spanning five insect orders, including adult Japanese beetles (Popillia japonica Newman [Coleoptera]), evergreen bagworm (Thyridopteryx ephemeraeformis Haworth), eastern tent caterpillar (Malacosoma americanum (F.) [Lepidoptera]), bristly roseslug sawfly (Cladius difformis Panzer [Diptera]), hawthorn lace bug (Corythuca cydoniae Fitch), oleander aphid (Aphis nerii Boyer de Fonscolombe), boxwood psyllid (Cacopsylla busi L.), oak lecanium scale crawlers (Parthenolecanium quercifex (Fitch) [Hemiptera]), and boxwood leafminer (Monarthropalpusi flavus (Schank) [Diptera]). All trials were done with fieldcollected insects on detached shoots or leaves that had been treated in the field or else targeted naturally occurring pest populations in landscape settings. Chlorantraniliprole (Acelepryn 1.67 SC; $18.4 \% \mathrm{AI}$ ) was used in all trials, along with other insecticides as standards (Table 1). Foliar sprays were applied with separate, handheld one-liter spray bottles to thoroughly wet abaxial and adaxial leaf surfaces. Systemic insecticides were applied via basal soil drench. Drench volumes and other methodological details are given in the descriptions of individual trials.

Most data sets were analyzed by Analysis of Variance (ANOVA) for a randomized complete block design (type I error rate of 0.05), with mean separation by Fisher's Least Significant Difference (LSD) test when the overall treatment effect was significant. Log- or square-root transformations were applied in a few cases where the data failed to meet ANOVA requirements for normality and homogeneity of variance. All analyses were performed with Statistix 9 (Analytical Software 2008). Data are reported as original (non-transformed) means \pm standard error (SE). 
Table 1. Products and label rates used to compare efficacy of chlorantraniliprole and other insecticides in trials against pests of woody ornamental plants (reduced rates were also tested in some trials).

\begin{tabular}{|c|c|c|c|c|c|}
\hline Active ingredient & Trade name & $\% \mathrm{AI}$ & Label rate & Manufacturer & Target $^{2}$ \\
\hline $\begin{array}{l}\text { Applied as foliar sprays } \\
\text { chlorantraniliprole }\end{array}$ & Acelepryn & 18.4 & $\begin{array}{l}0.312 \mathrm{ml} / \mathrm{L} \\
(4.0 \mathrm{fl} \mathrm{oz} / 100 \mathrm{gal})\end{array}$ & Syngenta & All \\
\hline carbaryl & Sevin SL & 43 & $\begin{array}{l}2.5 \mathrm{ml} / \mathrm{L} \\
(32 \mathrm{fl} \mathrm{oz} / 100 \mathrm{gal})\end{array}$ & Bayer & $\mathrm{JB}, \mathrm{RS}$ \\
\hline bifenthrin & Talstar P & 7.9 & $\begin{array}{l}0.78 \mathrm{ml} / \mathrm{L} \\
(10 \mathrm{fl} \mathrm{oz} / 100 \mathrm{gal})\end{array}$ & FMC & $\begin{array}{l}\text { JB, OLS, } \\
\text { HLB, OA }\end{array}$ \\
\hline B. thuringiensis & Thuricide & 15 & $\begin{array}{l}0.52 \mathrm{ml} / \mathrm{L} \\
(6.7 \mathrm{fl} \mathrm{oz} / 100 \mathrm{gal})\end{array}$ & Bonide & BW \\
\hline spinosad & Conserve & 11.6 & $\begin{array}{l}0.47 \mathrm{ml} / \mathrm{L} \\
(6.0 \mathrm{fl} \mathrm{oz} / 100 \mathrm{gal})\end{array}$ & Dow AgroSciences & ETC \\
\hline $\begin{array}{l}\text { Applied as basal drench } \\
\text { chlorantraniliprole }\end{array}$ & Acelepryn & 18.4 & $24.25 \mathrm{ml} / \mathrm{m}(0.25 \mathrm{fl} \mathrm{oz} / \mathrm{ft})$ & Syngenta & All \\
\hline dinotefuran & Safari 20SG & 20 & $18.6 \mathrm{~g} / \mathrm{m}(0.2 \mathrm{oz} / \mathrm{ft})$ & Valent & BLM \\
\hline imidacloprid & Merit 75WP & 75 & $6.43 \mathrm{~g} / \mathrm{m}(0.07 \mathrm{oz} / \mathrm{ft})$ & Bayer & BLM, BP \\
\hline imidacloprid & Merit $2 \mathrm{~F}$ & 2 & $19.39 \mathrm{ml} / \mathrm{m}(0.2 \mathrm{fl} \mathrm{oz} / \mathrm{ft})$ & Bayer & JB, RS \\
\hline thiamethoxam & Meridian 25WG & 25 & $12.14 \mathrm{ml} / \mathrm{m}(0.125 \mathrm{fl} \mathrm{oz} / \mathrm{ft})$ & Syngenta & BLM \\
\hline
\end{tabular}

\section{Efficacy of Spray Applications to Foliage}

\section{Control of Japanese beetles and feeding damage on linden}

Three trials evaluated efficacy and longevity of chlorantraniliprole foliar sprays to control adult Japanese beetles (JB) and reduce their defoliation of linden (Tilia spp.), a preferred JB host plant. Beetles were field-collected with standard JB traps (Trécè, Adair, Oklahoma, U.S.), baited with food-type lures (2-phenyl-ethyl-propionate, eugenol, and geraniol, 3:7:3 ratio), and brought to the lab within four hours of capture. Sexes were separated by foretibial characters (Baumler and Potter 2007); males were discarded, and females were held overnight in bins with moist soil, without food, before each assay. Freshly caught beetles were used for each trial. All trials included an equal number of replicates with foliage from non-sprayed twigs as untreated checks.

\section{Residual activity against JB on foliage}

Trials in two successive summers, 2011 and 2012, compared efficacy and longevity of residues of chlorantraniliprole with residues of carbaryl (Sevin SL, 43\% AI, Bayer, Research Triangle Park, North Carolina, U.S.; both trials) and bifenthrin (Talstar
Professional Insecticide, 7.9\% AI; FMC, Philadelphia, Pennsylvania, U.S.; 2012 trial only) applied at their respective ornamental foliar application rates (Table 1). The 2011 study site was a planting of 30 young Tilia americana $\times$ euchlora 'Redmond' (3-4 m tall) on the University of Kentucky campus, Lexington, Kentucky, U.S. Two trees were selected for each treatment and sets of similarsized twigs where $\geq 12$ leaves each were tagged with color-coded flagging tape corresponding to different insecticides and residue ages. Abaxial and adaxial surfaces of all leaves on a given twig were sprayed to runoff on different dates corresponding to $28,21,14,7$, and 1 day(s) before the assay, with residues allowed to weather in the field under ambient conditions before being challenged with JB. Eight similar, undamaged leaves from each treatment and spray date were harvested on 13 July 2011, the morning of the challenge, and placed in individual Petri dishes (9 $\mathrm{cm}$ diameter). Five active female JB were added to each dish. Dishes were held at $26^{\circ} \mathrm{C}$ on a 14:10 light:dark cycle for 24 hours, after which the JB were then removed and each cohort of five was placed in a separate covered black plastic tray $(15 \mathrm{~cm} \times 28 \mathrm{~cm}, 5.1 \mathrm{~cm}$ height $)$, brought outdoors, and opened in direct sunlight. 
This "fly-off" assay rapidly distinguishes viable beetles (including ones initially feigning death), which invariably take flight from dead of moribund ones still remaining in the trays after $10 \mathrm{~min}$ utes (Baumler and Potter 2007). The leaves were photocopied, the copies were scanned, and the amount of leaf area eaten was determined with the software program Paint.NET v3.5.8 by adjusting the selection tolerance for each scan to determine the area of the whole leaf and the missing portions.

The trial was repeated in 2012 using similar methodology, except the study site was an on-campus planting of mature ( $>8 \mathrm{~m}$ tall) Tilia cordata, residues (including both carbaryl and bifenthrin as standards) were allowed to field-weather for 21,14 , or 7 days before being challenged with four JB per leaf and dish. After 24 hours, beetles and leaves were evaluated for viability and feeding damage, respectively, as described above.

\section{Efficacy of chlorantraniliprole at reduced rates}

A trial conducted in July 2012 evaluated reduced rates of chlorantraniliprole $(0.312,0.156,0.078$, and $0.039 \mathrm{ml}$ per L) for suppressing JB defoliation of Tilia cordata compared to the label rate of carbaryl (Table 1) and untreated check. Methodology was as above except that only one spray timing (seven days before challenge) was used.

\section{Control of evergreen bagworm on arborvitae}

Several hundred mid-sized bagworms were collected from an untreated arborvitae (Thuja sp.) hedge in Lexington, Kentucky, on 18 June 2012, and held without food for 24 hours. Test chambers were made from covered clear plastic cups $(473 \mathrm{ml})$ with a florist's water pick inserted through the lid over which a second clear plastic cup was inverted to form a cage. Twigs of arborvitae ( 7.5 to $9.0 \mathrm{~cm}$ long) were sprayed on both sides with either chlorantraniliprole $(0.312 \mathrm{ml} / \mathrm{L})$, Bacillus thuringiensis var. Kurstaki (Thurcide; Certis, Columbia, Maryland, U.S.) at $15.6 \mathrm{ml} / \mathrm{L}$, or left untreated as checks. Residues were allowed to dry, then a single twig was inserted into each water pick, and a single bagworm was placed on the twig. There were 40 arenas (replicates) per treatment. Bagworms were assessed for survival after 48 hours. Frass pellets produced by the bagworm during the trial period were air-dried, counted, and weighed. The trial was repeated using late-instar bagworms collected from the same arborvitae hedge on 24 July 2012. Other procedures were the same as described above.

At the latitude of Kentucky, evergreen bagworms hatch in mid- to late May and develop through seven larval instars during their 10-13 week feeding period. Instar distributions used in the trials were assessed by measuring head capsule widths (Kaufmann 1968) of 20 larvae at the conclusion of each assay. Larvae in the first trial were fourth and fifth instars (10\% and $90 \%$, respectively), and in the second trial were sixth and seventh instars (32\% and 78\%, respectively).

\section{Control of eastern tent caterpillar on crabapple}

Two trials were conducted targeting early-mid or mid-late instar eastern tent caterpillar (ETC) with 1- or 14-day-old residues of chlorantraniliprole $(0.312 \mathrm{ml} / \mathrm{L})$, respectively. Spinosad was included as a standard, along with untreated checks. Intact twigs with leaves on a mature chokecherry tree (Prunus virginiana) on the University of Kentucky campus were blocked by size and within-canopy location, tagged, and sprayed to runoff on 18 April 2016. Residues were allowed to field-dry for 24 hours; then five replicates of treated twigs with five or more intact leaves each were harvested, trimmed to $15-20 \mathrm{~cm}$ length, and inserted into florists' water picks in arenas similar to those described for the bagworm trials.

Tents containing ETC larvae were harvested from wild black cherry trees (Prunus serotina) in Madison Co., Kentucky, on 19 April 2016. Ten ETC (mix of second and third instars) were introduced to each arena and allowed to feed for 24 hours. Larvae were then scored as dead, moribund (slight twitching only in response to probe), or alive (crawling, defensive twitching, or capable of flipping over within three seconds). Each cohort was then rated for number of fecal pellets produced during the assay (1-5 scale corresponding to $<10,10-20,21-50,51-100$, or $>100$ pellets, respectively) and amount of overall feeding on the leaves was assessed as described for the JB assays.

The trial was repeated by harvesting twigs with foliage with 14-day-old residues from the same 
chokecherry tree on 2 May 2016, enclosing them in arenas as above, and challenging them with cohorts of five ETC (four fourth instar, one third instar) per arena. By then most of the ETC in central Kentucky had abandoned their tents for pupation, but researchers were able to collect enough tents with still-active larvae from black cherry trees in shaded locations to use in the assay. After the 24-hour feeding period, ETC mortality, fecal pellet production, and defoliation were evaluated as above.

\section{Control of roseslug sawfly on rose}

This trial was conducted on potted roses (Knockout $^{\oplus}$ variety Radrazz PP\#11836, about $61 \mathrm{~cm}$ tall) in $11.4 \mathrm{~L}$ pots, with six shrubs (replicates) per treatment. Treatments were chlorantraniliprole $(0.312$ $\mathrm{ml} / \mathrm{L})$, carbaryl $(2.5 \mathrm{ml} / \mathrm{L})$, and untreated control. The insecticides were applied with a hand-held spray bottle on 01 May 2012, thoroughly wetting all adaxial and abaxial leaf surfaces of the whole shrub. Plants were held in the greenhouse for 24 hours to allow residues to dry, and then moved outdoors. There was no rain between treatment and the first (three days) challenge. Challenges were made at $3,7,14$, and 21 days after application.

Late-instar bristly roseslug sawfly larvae were hand-collected from rose plantings in Lexington, Kentucky, immediately before each challenge and set up in the assays the same day. For each challenge, six sets of three undamaged connected leaflets were removed from plants. Leaflets were placed on moistened filter paper in a $9 \mathrm{~cm}$ Petri dish, and five roseslug larvae were placed on the surface of the leaflets. Test arenas were maintained at $26^{\circ} \mathrm{C}$ on a $14: 10$ light:dark cycle. Roseslugs were assessed for mortality after 24 hours, and then feeding damage (leaf area consumed) was measured as described for the JB trials.

\section{Foliar sprays targeting lace bugs, aphids, and soft scale crawlers}

A trial comparing efficacy of 1- or 7-day-old foliar spray residues of chlorantraniliprole and bifenthrin against hawthorn lace bugs was conducted on mature ( $>10$ years old; $4-5 \mathrm{~m}$ tall) hawthorn trees (Crataegus viridis 'Winter King') on the University of Kentucky campus in 2016. On 03 August 2016, twigs with 5-10 leaves were tagged and sprayed to runoff at label rates (Table 1). There were six sets of twigs for each treatment and challenge date, blocked and distributed across six trees, with twigs within trees at least $1 \mathrm{~m}$ apart and nonsprayed twigs as checks. Another set of twigs was tagged and treated as above on 10 August 2016. On 11 August 2016, one leaf was removed from each twig; then the detached leaves with field-weathered residues (or checks) were placed into individual Petri dishes on moistened filter paper. There were six replicates per treatment and timing. Adult lace bugs were collected by beating branches of a heavily infested unsprayed hawthorn at a different campus location. Ten active adults were placed on the abaxial side of each leaf, leaves were then inverted, and the lidded plates were held at $25^{\circ} \mathrm{C}$ under a 14:10 light:dark cycle. After 24 hours, the insects were gently brushed off the leaves, leaves were removed, and the bugs were allowed three hours to crawl out of the open dishes and disclose their status as live and mobile. Bugs still in the dishes after three hours were probed, and those not capable of crawling or flipping over were scored as dead.

Another trial compared efficacy of chlorantraniliprole and bifenthrin sprays against oleander aphids (Aphis nerii) on small (10-15 cm tall) greenhouse-grown swamp milkweed (Asclepias incarnata var. 'Ice Ballet') plants in $10 \mathrm{~cm} \times 10$ $\mathrm{cm}$ pots. The plants were infested by placing field-collected swamp milkweed shoots with high numbers of aphids in the flats amongst the test plants and allowing the aphids to establish for four days before the trial. On 29 August 2016, 24 shoots, enough for eight replicates plus untreated checks, were selected and blocked by initial infestation level. Individual plants were gently sprayed to runoff using a hand-held spray bottle so that no aphids were physically knocked off the plants. Plants with aphids were then held in an incubator as described in the lace bug trial. Surviving aphids were counted after 48 hours.

Researchers also evaluated chlorantraniliprole as a foliar spray targeting active and newly settled oak lecanium scale nymphs that hatch from eggs laid by females on twigs and then move to leaves upon which they settle and feed from late spring through summer. The study site was a heavilyinfested planting of mature willow oaks (Quercus phellos) in a parking lot on the University of Kentucky campus. The application was made on 
09 June 2009 near the end of crawler hatch. Three twigs with $\geq 20$ leaves each were tagged on each of four trees and the bark and foliage was sprayed to runoff with chlorantraniliprole $(0.156 \mathrm{ml} / \mathrm{L})$ or bifenthrin $(0.78 \mathrm{ml} / \mathrm{L})$, or left untreated. On 23 June 2016, 14 days after treatment, researchers harvested the tagged branches, brought them to the lab, and counted numbers of live settled crawlers on both abaxial and adaxial surfaces of five randomly chosen, fully expanded leaves per shoot, which were pooled to give a single total per shoot.

\section{Efficacy of Systemic Soil Applica- tions on Boxwood and Rose Pests Systemic applications targeting boxwood pests}

A trial assessing efficacy of autumn or spring soil drenches of chlorantraniliprole for systemic control of boxwood psyllid [Cacopsylla busi (L.)], and boxwood leafminer (Monarthropalpusi flavus (Schank)] was done on established boxwood shrubs (Buxus sempervirens) at the Lexington Cemetery, Lexington, Kentucky. Both pests have a single generation per year with key life history events occurring during leaf flush (hatching and feeding of psyllid nymphs; emergence and egglaying by leafminer adults). Imidacloprid (Merit $75 \mathrm{WP}$ ) was included as a standard. The shrubs (0.6-0.9 $\mathrm{m}$ height) were located in four sections of the cemetery, were at least $100 \mathrm{~m}$ apart, with one shrub (replicate) per treatment in each section. The insecticides were mixed with water and applied as a basal drench using $2.33 \mathrm{~L}$ solution per meter of plant height at the rates listed in Table 1, without additional irrigation. Separate sets of shrubs were treated in October 2009 or April 2010. Total rainfall was 14.7 and $22.8 \mathrm{~cm}$ during the six week periods following the October and April applications, respectively, which was 3.8 and $7.4 \mathrm{~cm}$ above average for those periods.

Damage from boxwood psyllids was evaluated on 30 July 2010 by examining 20 twigs per shrub (10 each from the upper and lower canopy) and recording the number with characteristic rosettes of cupped, stunted, terminal leaves that result from the psyllids' feeding during leaf flush.

Boxwood leafminers were sampled twice, on 04 May 2010 for larvae already in the leaves at the time of the October 2009 drench, and on 13
October 2010 for larvae originating from eggs laid in spring 2010. For the May sampling, researchers collected 10 mined leaves per plant from the 2009 flush of growth and counted the number with live larvae, pupae, or exit holes. For the October sampling, researchers removed 20 random twigs per shrub and stereoscopically examined the first five leaves on each twig for living larvae.

Another trial targeting boxwood leafminer was done on heavily-infested in-ground $B$. sempervirens (0.6-0.9 $\mathrm{m}$ height) planted at a wholesale nursery in Stamping Ground, Kentucky. There were five replicates, each in a separate nursery row, with skips (untreated plants) between treated ones in a given row. Rows were $2.44 \mathrm{~m}$ apart and separated by mowed grass. Insecticides were applied as a basal drench on 23 April or 13 May 2013, using 3.1 L solution per meter of plant height at the rates listed in Table 1, without additional irrigation. The two timings tested for possible differences in efficacy from application just before or soon after leaf flush, which is when adults emerge from the previous year's leaves and oviposit in new leaves. Treatments included chlorantraniliprole (both treatment dates) and two standards: dinotefuran (23 April only) or thiamethoxam (13 May only), plus untreated checks. There was $19.1 \mathrm{~cm}$ total rainfall from 23 April to 1 June 2013, $4.8 \mathrm{~cm}$ above normal for that period, and during summer the plants received occasional irrigation from the nursery's sprinkler system, as needed to maintain vigor. Efficacy was assessed on 09 October 2013 by clipping 10 twigs per shrub from all parts of the canopy. Three fully-expanded leaves from each twig were dissected, and the number of leaves (out of 30 per plant) with live miners and living larvae per leaf was recorded.

\section{Systemic applications targeting rose pests}

This trial evaluated autumn soil drenches of chlorantraniliprole for reducing foliar damage by roseslug sawfly larvae and JB in the following growing season. It was conducted on established, similar-sized (about $60 \mathrm{~cm}$ height) hybrid tea ('Knockout') rose shrubs growing in several mulched beds on the university campus. The layout was a completely randomized design with five replicates. Treatments included chlorantraniliprole and imidacloprid (Merit 2F) at the 
rates listed in Table 1, chlorantraniliprole at half rate $(12.13 \mathrm{ml} / \mathrm{m})$, and untreated checks. The insecticides were applied via basal drench $(1 \mathrm{~L}$ per shrub) on 23 October 2015. The plants were not subsequently irrigated, but there was $11.9 \mathrm{~cm}$ of rainfall from 23 October to 1 December 2015, which was $1.3 \mathrm{~cm}$ above normal for that period.

Roseslug sawfly damage was evaluated 03 May 2016 by two observers who independently counted all current-year leaves on each shrub with that pest's characteristic window-feeding and skeletonization. On 28 June, twigs bearing five intact leaflets each were harvested from each plant, placed in $0.24 \mathrm{~L}$ transparent dishes, and challenged with five field-collected JB females that had been starved overnight. The JB were allowed to feed for 24 hours, remaining leaf material was scanned to determine amount eaten $\left(\mathrm{cm}^{2}\right)$, and beetle vigor was assessed with a fly-off assay. Methods were as described earlier for evaluating foliar sprays for JB on linden.

\section{RESULTS}

\section{Control}

\section{Japanese beetles and feeding damage on linden}

Field-weathered dry residues of chlorantraniliprole gave nearly complete suppression of JB feeding for at least 28 days, longer than either standard in the 2011 trial (Figure 1A). Carbaryl began losing activity after 7-14 days, whereas bifenthrin was as effective as chlorantraniliprole after 14 days, but slightly less so after 28 days (Figure 1A). Data for 7- and 21-day-old residues of the respective insecticides (not shown) showed a similar pattern. Chlorantraniliprole also gave as good or better "knockdown" of JB than did the standards. Mean numbers of beetles (out of 5) capable of flight after feeding for 24 hours on leaves with 1-day-old dry residues on chlorantraniliprole, bifenthrin, or carbaryl (label rates) were $0.6 \pm 0.2,0.9 \pm 0.05$, and 0 , respectively, compared to $5.0 \pm 0.0$ for cohorts feeding on the untreated leaves $\left(F_{3,19}=64.0, P<\right.$ 0.001 ). Numbers of flight-capable beetles (out of 5) were $0.4 \pm 0.4,4.0 \pm 0.3,3.1 \pm 0.6$, and 3.8 \pm 0.5 , for cohorts provided leaves with 14 -dayold residues of chlorantraniliprole, bifenthrin, or carbaryl, or untreated foliage, respectively $\left(F_{3,19}=18.6, P<0.001\right)$. In 2012, chlorantraniliprole again gave longer-lasting suppression than did either standard (Figure 1B). Reduced rates of chlorantraniliprole were as effective as the full label rate of bifenthrin (Figure 1C).
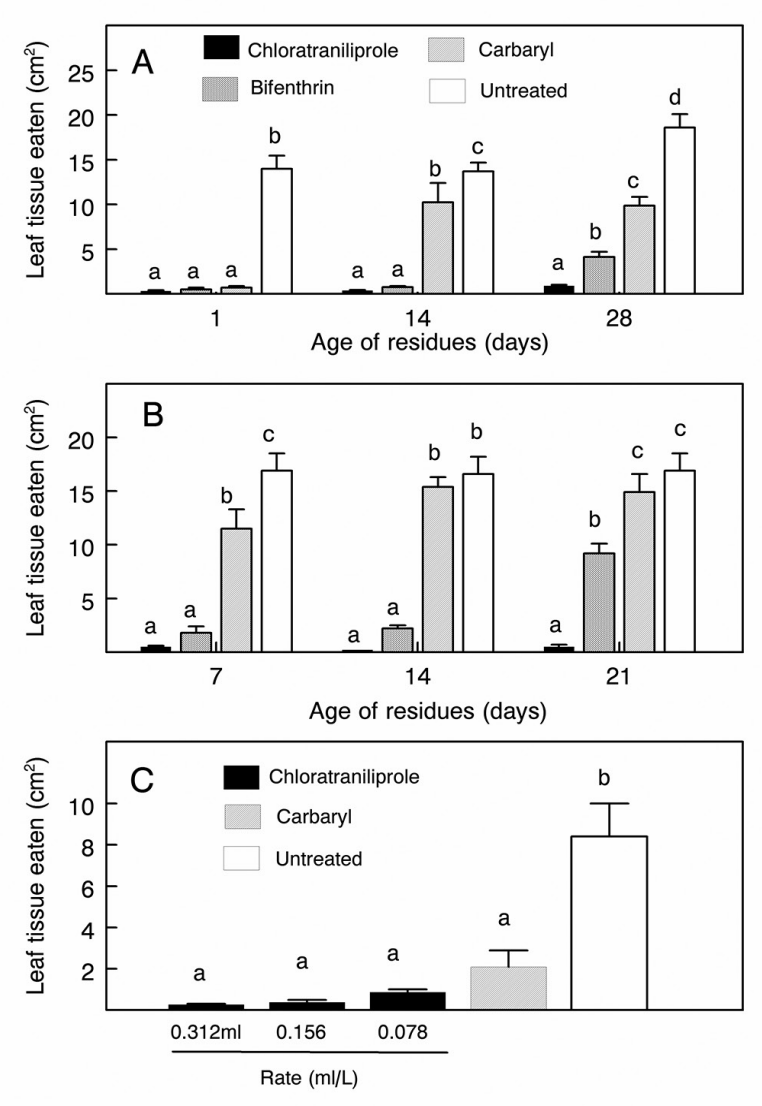

Figure 1. Three trials comparing field-weathered residues of chlorantraniliprole and insecticide standards for reducing Japanese beetle feeding on linden foliage. A) Trial 1 (2011): $F_{3,2} 1=96.9,43.3$, and 126.9 for $1-, 14-$, and 28-day-old residues, respectively; $P<0.001$; B) Trial 2 (2012): $F_{3,21}=50.5$, 107.6, and 36.9 for 7-, 14-, and 21-day-old residues, respectively; $P<0.001$; C) Trial 3 (2012, reduced rates of chlorantraniliprole, 7-day-old residues): $F_{4,28}=21.6 ; P<0.001$. Within trial and residue age, means not topped by the same letter are significantly different (LSD; $\boldsymbol{P}<\mathbf{0 . 0 5}$ ).

\section{Evergreen bagworm on arborvitae}

Early instar bagworms feeding on arborvitae foliage with chlorantraniliprole or $B$. thuringiensis residues suffered $100 \%$ and $80 \%$ mortality, respectively, within 48 hours (Figure 2A). Although the proportion of early instars killed (out of 40) did not differ between those treatments (Fisher's exact test, $P=0.52$ ), chlorantraniliprole 
killed proportionately more late instars within 48 hours (Fisher's exact test, $P<0.001$; Figure $2 \mathrm{~A}$ ). Both treatments rapidly reduced frass production, indicating cessation of feeding (Figure 2B).

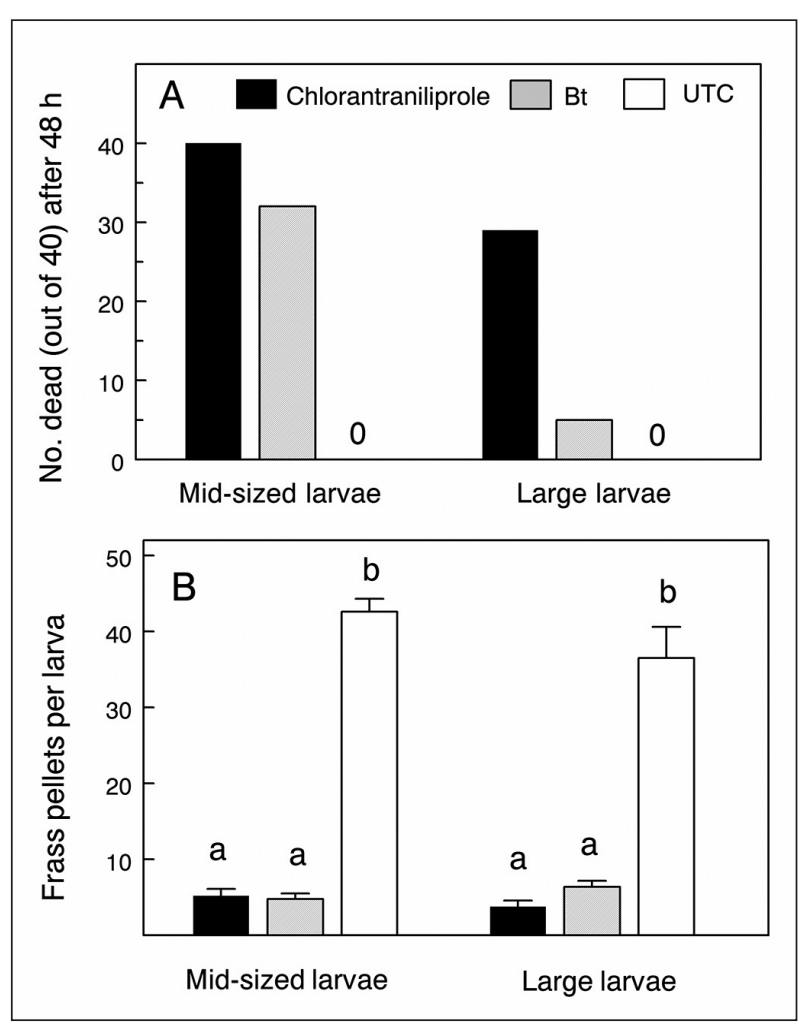

Figure 2. Mortality and frass production (indicative of feeding) of cohorts of mid-sized (mostly fifth instar) or large (mostly seventh instar) evergreen bagworms 48 hours after confinement on arborvitae shoots with dry residues of chlorantraniliprole (Chlor) or Bacillus thuringiensis var. Kurstaki (Bt) compared to cohorts on untreated checks (UTC). Upper graph: Both treatments controlled mid-sized larvae but chlorantraniliprole was more effective against late instars (Fisher's exact test, see text). Lower graph: Both treatments reduced frass production indicating cessation of feeding $\left(F_{2,77}=223, F_{2,67}=43.1\right)$ for mid-sized and large larvae, respectively; both $P<0.001$; within size classes, means topped by same letter are not significantly different (LSD, $P=0.05$ ).

\section{Eastern tent caterpillar on crabapple}

One-day-old residues of chlorantraniliprole or spinosad gave comparable control of early instar ETC (second and third instar); each significantly reduced survival, frass production, and defoliation within 24 hours (Table 2). Field-weathered 14-day-old residues of both insecticides also reduced survival and frass production by later (mostly fourth) instars, and chlorantraniliprole also suppressed the amount of defoliation caused relative to cohorts in untreated leaves (Table 2).

\section{Roseslug sawfly on rose}

Field-weathered dry residues of chlorantraniliprole on rose foliage killed roseslug sawfly larvae and prevented feeding damage for at least 14 and 21 days, respectively, significantly longer than did carbaryl (Figure 3A). Although only about $20 \%$ of the larvae on leaves with 21-day-old chlorantraniliprole residues were killed outright, survivors' feeding was completely shut down (Figure 3B).

\section{Lace bugs, aphids, and soft scale crawlers}

Foliar sprays of chlorantraniliprole were ineffective for residual control of hawthorn lace bugs (Figure 4). In contrast, 1- and 7-days-old residues of bifenthrin gave $95 \%$ and $47 \%$ control, respectively, relative to mortality in the untreated check (Figure 4A). Chlorantraniliprole sprays also failed to curatively control oleander aphids on swamp milkweed seedlings, whereas bifenthrin sprays gave $>99 \%$ control (Figure 4B).

Spraying oak twigs and leaves with chlorantraniliprole near the end of crawler hatch and during crawler settlement did not significantly reduce

Table 2. Efficacy of 1- or 14-day-old field-weathered residues of chlorantraniliprole or spinosad for control of early or late instars of the eastern tent caterpillar (Malacosoma americanum) on black cherry foliage.

\begin{tabular}{|c|c|c|c|c|c|c|}
\hline \multirow[b]{2}{*}{ Treatment $^{\mathrm{z}}$} & \multicolumn{3}{|c|}{ One-day-old residues versus early instars ${ }^{y}$} & \multicolumn{3}{|c|}{ 14-days-old residues versus late instars ${ }^{\mathrm{x}}$} \\
\hline & $\begin{array}{l}\text { No. surviving } \\
\text { (of 10) }\end{array}$ & $\begin{array}{l}\text { Frass } \\
\text { rating }\end{array}$ & $\begin{array}{l}\text { Leaf area } \\
\text { eaten }\left(\mathrm{cm}^{2}\right)\end{array}$ & $\begin{array}{l}\text { No. alive } \\
\text { (of } 5 \text { ) }\end{array}$ & $\begin{array}{l}\text { Frass } \\
\text { rating }\end{array}$ & $\begin{array}{l}\text { Leaf area } \\
\text { eaten }\left(\mathrm{cm}^{2}\right)\end{array}$ \\
\hline Chlorantraniliprole & $2.4 \pm 1.2 \mathrm{a}$ & $3.2 \pm 0.4 b$ & $2.0 \pm 0.4 \mathrm{a}$ & $2.6 \pm 0.4 \mathrm{~b}$ & $3.6 \pm 0.2 \mathrm{a}$ & $36 \pm 5 a$ \\
\hline Spinosad & $1.6 \pm 1.4 \mathrm{a}$ & $2.2 \pm 0.4 \mathrm{a}$ & $1.8 \pm 0.5 \mathrm{a}$ & $1.0 \pm 0.3 \mathrm{a}$ & $3.8 \pm 0.2 \mathrm{a}$ & $46 \pm 11 \mathrm{ab}$ \\
\hline Untreated & $10.0 \pm 0.0 \mathrm{~b}$ & $5.0 \pm 0.0 \mathrm{c}$ & $4.6 \pm 0.9 \mathrm{~b}$ & $4.6 \pm 0.4 \mathrm{c}$ & $4.8 \pm 0.2 \mathrm{~b}$ & $72 \pm 10 b$ \\
\hline
\end{tabular}

${ }^{\mathrm{z}}$ Rates as in Table 1. Trials were evaluated 24 hours after larvae were introduced.

${ }^{y}$ Larval cohorts consisted of second and third instars. ANOVA: $F_{2,12}=19.4,21.6,6.1 ; P<0.001, P<0.001$, and $P<0.015$ for survival, frass, and area eaten, respectively. Means $( \pm \mathrm{SE})$ not followed by the same letter differ significantly (LSD, $P<0.05$ ).

${ }^{x}$ Larval cohorts consisted of four fourth instars and one third instar. ANOVA (late instar data): $F_{2,12}=23.2,8.9,4.1 ; P<0.001, P<0.001$, and $P<0.05$ for survival, frass, and area eaten, respectively. Means $( \pm \mathrm{SE})$ not followed by the same letter differ significantly $(\mathrm{LSD}, P<0.05)$. 


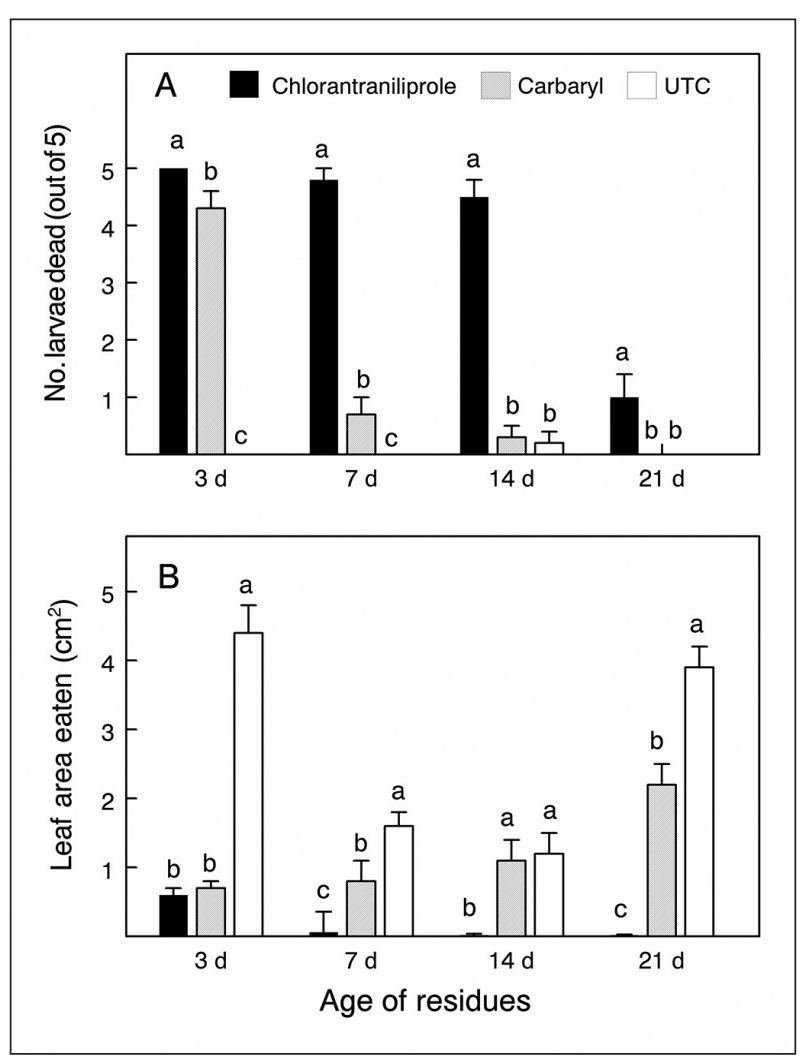

Figure 3. Residual control of bristly roseslug larvae and their feeding damage by sprayed field-weathered residues of chlorantraniliprole or carbaryl on rose foliage, compared to untreated checks (UTC). The pre-sprayed shoots were harvested after their respective weathering intervals and challenged with separate cohorts of similar-sized larvae all on the same day. Note the longer residual efficacy of chlorantraniliprole than carbaryl. Within residue ages, means not topped by the same letter are significantly different (ANOVA, LSD, $P<0.05$ ).

numbers of live settled oak lecanium scale crawlers, whereas bifenthrin gave about $96 \%$ control. Mean numbers of living settled crawlers (totals for five leaves per shoot) for untreated checks, chlorantraniliprole, and bifenthrin were $1093 \pm$ $460,1141 \pm 811$, and $49 \pm 10$, respectively $\left(F_{2,6}\right.$ $=28.7, P<0.001$ on log-transformed counts).

\section{Efficacy of Systemic Soil Applica- tions on Boxwood and Rose Pests \\ Systemic applications targeting boxwood pests}

Chlorantraniliprole applied as a basal soil drench in the preceding autumn (October) or in spring (April) before leaf flush failed to prevent boxwood psyllid damage or to reduce in-

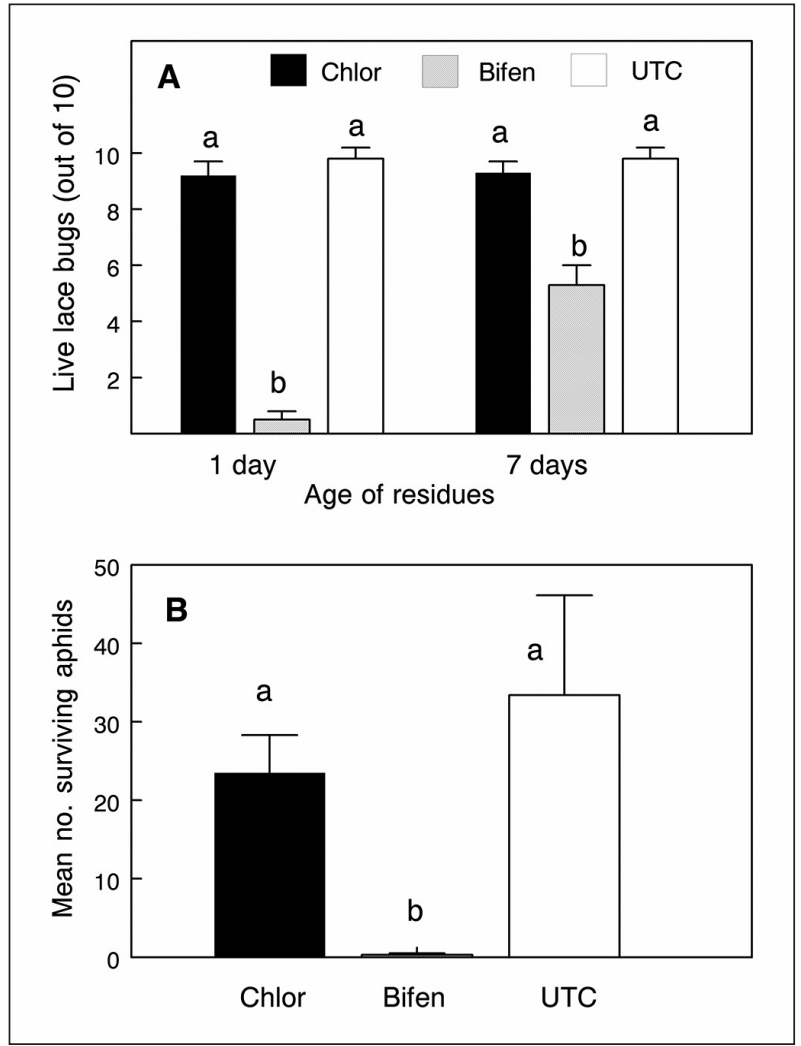

Figure 4. Lack of efficacy of chlorantraniliprole (Chlor) foliar sprays for: A) residual control of hawthorn lace bugs, or B) curative control of oleander aphids on milkweed, in trials where the standard, bifenthrin (Bifen), was effective. Data are means $( \pm \mathrm{SE})$ per replicate. UTC $=$ untreated check. For lace bugs, $F_{2,10}=244,22.4$ for 1 - and 7-day-old residues, respectively, $P<0.001$; for aphids, $F_{2,21}=49.9, P<0.001$. Within trials, means topped by the same letter are not significantly different (LSD, $P>0.05$ ).

festations of boxwood leafminer (Table 3). Imidacloprid, the standard, gave $89 \%$ reduction in psyllid damage from the October treatment, and $90 \%$ and $99 \%$ control of leafminers when applied in October or April, respectively.

Basal drenches with chlorantraniliprole in April or May also failed to control boxwood leafminer infesting in-ground boxwoods at the wholesale nursery. Mean \pm SE numbers of mined leaves (out of 30) on those shrubs, assessed in October, were $19 \pm 3$ and $15 \pm 4$ for the April and May chlorantraniliprole drenches, compared to $22 \pm 1$ for untreated shrubs $\left(F_{2,8}\right.$ $=1.3, P=0.33$ ). Both standards (dinotefuran and thiamethoxam) gave 100\% control. 
Table 3. Comparison of chlorantraniliprole and imidacloprid as a basal soil drench targeting boxwood psyllid and boxwood leafminer on established boxwoods in Lexington Cemetery.

\begin{tabular}{|c|c|c|c|c|c|}
\hline \multirow[b]{2}{*}{ Treatment } & \multirow[b]{2}{*}{$\begin{array}{l}\text { Application } \\
\text { date }^{z}\end{array}$} & \multicolumn{2}{|l|}{ Psyllids } & \multicolumn{2}{|l|}{ Leafminers } \\
\hline & & $\begin{array}{l}\text { Damaged twigs } \\
(\text { of } 20)^{y}\end{array}$ & $\%$ reduction & $\begin{array}{l}\text { Mined leaves } \\
(\text { of } 100)^{x}\end{array}$ & $\%$ reduction \\
\hline Chlorantraniliprole & October & $7.3 \pm 1.2$ & - & $61 \pm 30$ & - \\
\hline Imidacloprid & October & $0.5 \pm 1.0^{*}$ & 88.9 & $6 \pm 4^{*}$ & 89.7 \\
\hline Chlorantraniliprole & April & $4.8 \pm 3.4$ & - & $70 \pm 18$ & - \\
\hline Imidacloprid & April & $2.0 \pm 1.4$ & - & $0.8 \pm 0.8^{*}$ & 98.7 \\
\hline Untreated & - & $4.5 \pm 3.7$ & - & $61 \pm 20$ & - \\
\hline
\end{tabular}

${ }^{\mathrm{z}}$ Applications were in October 2009 or April 2010.

y Mean ( \pm SE) no. of twigs (out of 20) with current year's showing psyllid damage (cupped terminal leaves); evaluated July 2010.

${ }^{x}$ Based on five leaves from each of 20 randomly selected twigs per shrub; evaluated 13 October 2010.

Notes: ANOVA results: for psyllids, $F_{4,20}=7.5, P<0.001$; for leafminers, $F_{4,14}=4.2, P<0.02$. Asterisk $\left(^{*}\right)$ denotes significant reduction relative to untreated check (Dunnett's test, $P<0.05)$

\section{Systemic Applications Targeting Rose Pests}

Chlorantraniliprole basal soil drench in October significantly reduced (about 70\%) naturallyoccurring roseslug sawfly damage on rose shrubs the following spring (Figure 5A). Imidacloprid, the standard, also was effective. Both treatments reduced Japanese beetle feeding on detached leaflets compared to the amount of feeding on leaflets from untreated checks (Figure $5 \mathrm{~B})$. Most of the beetles were still viable enough for flight in the post-assay fly-off test, with no difference between treatments $\left(F_{2,8}=3.63 ; \mathrm{ns}\right)$.

\section{DISCUSSION}

Pesticides used to protect woody ornamentals and turf in urban landscapes need to have efficacy against target pests, low mammalian and avian toxicity, stability of performance across different conditions, and minimal impact on pollinators, natural enemies, earthworms, and other beneficial invertebrates. Chlorantraniliprole meets those criteria (Dinter et al. 2008a; Dinter et al 2008b; Brugger et al. 2009; Gradish et al. 2010; Gradish et al. 2011; Larson et al. 2012; Larson et al. 2013; Larson et al. 2014), making it an attractive alternative to neonicotinoids, pyrethroids, and older chemistries, especially for use on plants that may attract bees. The trials demonstrated its strong performance as a foliar spray for control of Japanese beetle adults, bagworms, eastern tent caterpillars, and bristly roseslugs-leaf-chewing pests in three insect orders. Against those pests, the efficacy and residual activity of foliar applications were equivalent or better than those provided by industry standards applied in the same manner.

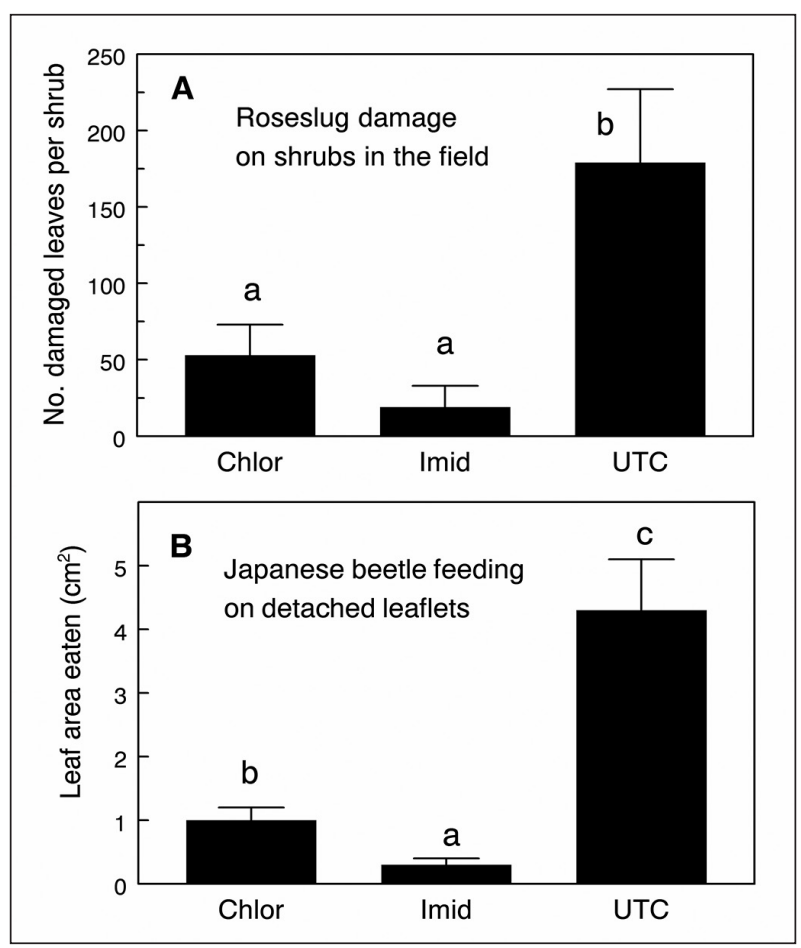

Figure 5. Basal soil drenches with chlorantraniliprole (Chlor) or imidacloprid (Imid) in October reduced naturallyoccurring roseslug sawfly damage to foliage of in-ground roses $\left(F_{2,8}=7.24, P=0.02\right)$ as well as Japanese beetle feeding on detached leaflets $\left(F_{2,8}=26.0, P<0.001\right)$. UTC $=$ untreated check. Within trials, means $( \pm S E)$ topped by the same letter are not significantly different (LSD, $P>0.05$ ).

Residual activity on foliage is particularly useful for products used to manage leaf-chewing pests, such as Japanese beetles that have a relatively long seasonal flight and mobile adults, different individuals of which may re-infest the same plants for four to six weeks or longer (Baumler and Potter 2007), and when controlling pests with prolonged emergence or multiple overlapping generations. Bristly 
roseslug, for example, has about six generations per growing season at the latitude of Washington, D.C., with much overlapping due to variation in emergence of overwintering adults and in individual development, such that all life stages may be present at the same time (Middleton 1922). Biological insecticides, such as Bacillus thuringiensis, azadirachtin, or spinosad, and older synthetic insecticides, such as carbaryl or malathion, may require weekly applications, and even pyrethroids may require multiple applications to protect plants from such pests. Use of chlorantraniliprole could reduce the number of applications needed to do so.

The 2017 federal label for chlorantraniliprole (Acelepryn, Syngenta, Greensboro, North Carolina, U.S. ) for landscape and turf usage lists a limited range of target pests: leaf-feeding caterpillars (foliage application), lace bugs, aphids, and birch leafminer (soil treatment), and clearwing borers (bark treatment), although a Section 2 (ee) label recommendation extends the list of target pests to include Japanese beetle adults and sawfly larvae (foliar application), and rhododendron lace bug, Japanese beetle adults, magnolia scale (autumn application only), and hemlock woolly adelgid (soil treatment). Labels of formulations (Coragen, Altacor; E.I. du Pont de Nemours, Wilmington Delaware, U.S.) used on agronomic crops list a wide range of lepidopteran pests, Colorado potato beetle, Japanese beetle adults, and some dipteran (Liriomyza sp.) leafminers as targets for foliar sprays or drip irrigation. Based on chlorantraniliprole's activity spectrum, it should control a wide range of plant-chewing caterpillars, beetles, and sawfly larvae on woody ornamentals. Researchers suspect it may also be effective against larvae of certain leaf-mining flies; e.g., Phytomyza spp. in columbine. Chlorantraniliprole's efficacy against bagworms on arborvitae was previously reported (Rhainds and Sadof 2009) but researchers found no other publications in refereed scientific journals characterizing its performance as a foliar spray for pests of woody landscape plants. More research is needed to fill those gaps.

Although chlorantraniliprole has intrinsic activity against hemipteran RyRs, its relatively low systemicity in plants limits its usefulness against sap-feeding insects (Hamaguchi et al. 2011; Selby et al. 2013; Selby et al. 2016). In trials, it was inef- fective as a foliar spray for lace bugs, aphids, or scale crawlers. It also failed to prevent damage from boxwood psyllids, or to reduce infestations of boxwood leafminer (Diptera), when applied as a basal soil drench in trials in which the neonicotinoid standards gave excellent control. Surface drenches with chlorantraniliprole also exhibited little systemic activity against adults of the black vine weevil (Otiorhynchus sulcatus) in containerized nursery crops (Reding and Persad 2009; Reding and Ranger 2011). The autumn, basal soil drench application to in-ground roses did suppress damage from both roseslugs and Japanese beetles in the subsequent growing season, although in the latter case, it was not as effective as drenching with imidacloprid.

A second anthranilic diamide, cyantraniliprole (Mainspring ${ }^{\circledR} \mathrm{GNL}$, Syngenta, Greensboro, North Carolina, U.S.) is labeled foliar and systemic insect control on ornamental plants, including woody ornamentals in residential and commercial landscapes. It has activity against multiple insect orders, including both sap-feeders (e.g., aphids, adelgids, leafhoppers, psyllids, soft scales, and whiteflies), leaf-chewing beetles and caterpillars, leafminers, thrips, borers, and certain other pests. It is more water-soluble than chlorantraniliprole, with strong upward root movement from soil applications, and translaminar leaf movement in foliar applications (Dinter et al. 2012; Selby et al. 2013; Selby et al. 2016). Both anthranilic diamides are at least 500-fold less potent against mammalian RyRs than against insect RyRs, which translates to very low mammalian toxicity (Selby et al. 2016). However, cyantraniliprole, unlike chlorantraniliprole, is highly toxic to bees exposed to direct treatment or residues on blooming plants.

Neonicotinoid insecticides have the potential to cause outbreaks of spider mites on woody ornamentals both by stimulating their fecundity though plant-mediated mechanisms, and by killing the arthropod natural enemies that normally help to keep pest populations in check (Szczepaniec et al. 2011; Szczepaniec and Raupp 2013). Pyrethroids, too, have acute and sublethal effects on predatory and parasitic insects that can in turn provoke secondary pest outbreaks (Theiling and Croft 1988; Desneux et al. 2007). Although they are not benign to all natural enemies (e.g., lacewings; Amarasekare and Shearer 2013), neither chlorantranilip- 
role nor cyantraniliprole has been associated with outbreaks of mites or other secondary pests.

Compared to habitat loss and homogenization, decreased abundance and diversity of floral resources, parasites, pathogens, and other stress factors, the use of insecticides on woody ornamentals is probably a very minor contributor to urban bee decline. There are several reasons why that is so. Surveys show that most woody ornamentals in suburban neighborhoods are never infested with sufficient densities of arthropod pests to require intervention (Raupp and Noland 1984; Raupp et al. 1985). Pest infestations on susceptible woody plants often go unrecognized and untreated. Many ornamental plants are horticulturally modified variants having double petals (e.g., many roses), corymbs covered with sterile florets (e.g., Hydrangea macrophylla), or other modifications that affect flower form and function. Such plants tend to produce little or no nectar or pollen and are not attractive to bees (Comba et al. 1999; Corbet et al. 2001; Mach et al. 2017). Woody ornamentals that are both pest-prone and bee-attractive (e.g., Crataegus, Malus, Prunus, Pyracantha) typically bloom for only one to two weeks per year. Many urban shade trees (e.g., oaks, birch, ash) are predominantly wind-pollinated, and although bees may visit them to collect pollen (Kraemer and Favi 2005; MacIvor et al. 2014), it is usually only during a brief period in spring.

Misapplication of broad-spectrum insecticides to blooming woody plants can nevertheless result in localized bee kills (e.g., Xerces Society 2013) and the backlash from such events fuels tighter restrictions on pesticides and reflects negatively on the whole landscape industry. Landscape professionals who incorporate best management practices for controlling pests without harming pollinators and other beneficial insects will be well-positioned to have a competitive advantage. The most impactful best management practices for urban pollinators is to provide them with more and better food; that is, creating and maintaining healthy landscapes with diverse flowering plants whose successive bloom periods provide sources or nectar and pollen throughout the growing season. Ideally those plants should be relatively pest-free species and cultivars that rarely if ever require an insecticide application. For those woody ornamentals that do occasionally require treatment, chlorantraniliprole is an effective option for controlling caterpillars, leaf-feeding beetles, sawfly larvae, and certain other pests, with very low hazard to bees.

Acknowledgments. The authors thank E.K. Dobbs, D. Hammons, A.J. Kesheimer, S. Marksbury, and S. Vanek for field assistance. Funding was provided in part by Dupont Crop Protection, Syngenta Crop Protection, and USDA-NIFA-SCRI grant 2016-51181-25399. This is paper number 17-08-014 of the Kentucky Agricultural Experiment Station.

\section{LITERATURE CITED}

Amarasekare, K.G., and P.W. Shearer. 2013. Comparing effects of insecticides on two green lacewings species, Chrysoperlajohnsoni and Chrysoperla carnea (Neuroptera: Chrysopidae). Journal of Economic Entomology 106:1126-1133.

Analytical Software. 2008. Statistix Version 9.0; User's manual. Analytical Software, Tallahassee, Florida, U.S.

Baumler, R.E., and D.A. Potter. 2007. Knockdown, residual, and antifeedant activity of pyrethroids and home landscape bioinsecticides against Japanese beetles (Coleoptera: Scarabaeidae) on linden foliage. Journal of Economic Entomology 100:451-458.

Besard L., V. Mommaerts, G. Abdu-Allaa, and G. Smagghe. 2011. Lethal and sublethal side effect assessment supports a more benign profile of spinetoram compared with spinosad in the bumblebee Bombus terrestris. Pest Management Science 67:541-554.

Blacquiere, T., G. Smagghe, C.A.M. Van Gestel, and V. Mommaerts. 2012. Neonicotinoids in bees: A review on concentrations, side effects, and risk assessment. Ecotoxicology 21:973-992.

Bonmatin, J.M., C. Giorio, V. Girolami, D. Goulson, D.P. Kreutzweiser, C. Krupke, M. Liess, E. Long, et al. 2015. Environmental fate and exposure; neonicotinoids and fipronil. Environmental Science and Pollution Research 22:35-67.

Brugger, K.E., P.G. Cole, I.C. Newman, N. Parker, B. Scholtz, P. Suvagia, G. Walker, and T.G. Hammond. 2009. Selectivity of chlorantraniliprole to parasitoid wasps. Pest Management Science 66:1075-1081.

Comba, L., S.A. Corbet, A. Barron, A. Bird, S. Collinge, N. Miyazaki, and M. Powell. 1999. Garden flowers: Insect visits and the floral reward of horticulturally-modified variants. Annals of Botany 83:73-86.

Corbet, S.A., J. Bee, K. Dasmahapatra, S. Gale, E. Gorringe, B. La Ferla, T. Moorhouse, et al. 2001. Native or exotic? Double or single? Evaluating plants for pollinator-friendly gardens. Annals of Botany 87:219-232.

Cordova, D., E.A. Benner, M.D. Sacher, J.J. Rauh, J.S. Sopa, G.P. Lahm, T.P. Selby, et al. 2006. Anthranilic diamides: A new class of insecticides with a novel mode of action, ryanodine receptor activation. Pesticide Biochemistry and Physiology 84:196-214.

Desneux, N., A. Decourtye, and J.M. Delpuech. 2007. The sublethal effects of pesticides on beneficial insects. Annual Review of Entomology 52:81-106.

Dinter, A., A. Samel, N.M. Frost, and F.L. Groya. 2012. Cyantraniliprole (DPX-HGW86, DuPont ${ }^{\mathrm{max}}$ Cyazpyr $^{\mathrm{mt}}$ ) - A novel DuPont insecticide with selectivity towards beneficial non-target arthropods. IOBC WPRS Bulletin 82:9-14. 
Dinter, A., K. Brugger, A. Bassie, N.M. Frost, and M.D. Woodward. 2008b. Chlorantraniliprole (DPX-E2Y45, DuPont ${ }^{\text {tx }}$ Rynaxypyr ${ }^{\oplus}$, Coragen $^{\circ}$, and Altacor ${ }^{\circledR}$ insecticide)-A novel anthranilic diamide insecticide-Demonstrating low toxicity and low risk for beneficial insects and predatory mites. IOBC WPRS Bulletin 35:128-135.

Dinter, A., K.E. Brugger, N.M. Frost, and M.D. Woodward. 2008a. Chlorantraniliprole (Rynaxypyr): A novel DuPont ${ }^{\text {txx }}$ insecticide with low toxicity and low risk for honey bees (Apis mellifera) and bumble bees (Bombus terrestris) providing excellent tools for uses in integrated pest management. pp. 84-96. In: P.A. Oomen and H.M. Thompson (Eds.). Hazards of Pesticides to Bees-10th International Symposium of the ICP-Bee Protection Group. Julius-Kühn-Archiv 423, Bucharest, Romania.

Godfray, H.C.J., T. Blacquiére, L.M. Field, R.S. Hails, G. Petrokofsky, S.G. Potts, N.E. Raine, A.J. Vanbergen, and A.R. McClean. 2014. A restatement of the natural science evidence base concerning neonicotinoid insecticides and insect pollinators. Proceedings of the Royal Society B. 281:20140558 <http://dx.doi. org/10.1098/rspb.2014.0558>

Goulson, D. 2013. Review: An overview of the environmental risks posed by neonicotinoid insecticides. Journal of Applied Ecology 20:977-987.

Goulson, D., E. Nicholls, C. Botias, and E.L. Rotheray. 2015. Bee declines driven by combined stress from parasites, pesticides, and lack of flowers. Science 347, $1255957<$ doi:10.1126/science.1255957>

Goulson, D., G.C. Lye, and B. Darvill. 2007. Decline and conservation of bumble bees. Annual Review of Entomology 53:91-208.

Gradish, A.E., C.D. Scott-Dupree, L. Shipp, C.R. Harris, and G. Ferguson. 2010. Effect of reduced risk pesticides for use in greenhouse vegetable production on Bombus impatiens (Hymenoptera: Apidae). Pest Management Science 66:142-146.

Gradish, A.E., C.D. Scott-Dupree, L. Shipp, C.R. Harris, and G. Ferguson. 2011. Effect of reduced risk pesticides on greenhouse vegetable arthropod biological control agents. Pest Management Science 67:82-86.

Hamaguchi, H., T. Hirooka, T. Masaki, G.P. Lahm, D. Cordova, J.D. Barry, J.T. Andaloro, I.B. Annan, et al. 2011. Insecticides affecting calcium homeostasis. pp. 1409-1425. In: W. Krämer, U. Schirmer, P. Jeschke, and M. Witschel (Eds.). Modern Crop Protection Compounds, vol. 3. Wiley-VCH, Weinheim, Germany.

Hannig, G.T., M. Ziegler, and P.G. Marçon. 2009. Feeding cessation effects of chlorantraniliprole, a new anthranilic diamide insecticide, in comparison with several insecticides in distinct chemical classes and mode-of-action groups. Pest Management Science 65:969-974.

Held, D.W., and D.A. Potter. 2012. Prospects for managing turfgrass pests with reduced chemical inputs. Annual Review of Entomology 57:329-354.

Hooven, L., R. Sagili, and E. Johansen. 2013. How to reduce bee poisoning from pesticides. Pacific Northwest Extension Publication PNW 591, Oregon State University, Corvallis, Oregon, U.S.

Inglesfield, C. 1989. Pyrethroids and terrestrial non-target organisms. Pesticide Science 27:387-428.

Isaacs, A.K.J., S. Qi, R. Sarpong, and J.E. Casida. 2012. Insect ryanodine receptor: Distinct but coupled insecticide binding sites for $[\mathrm{N}-\mathrm{C}(3) \mathrm{H}(3)]$ chlorantraniliprole, flubendiamide, and [(3) H]ryanodine. Chemical Research in Toxicology 25:1571-1573.
Kaufmann, T. 1968. Observations on the biology and behavior of the evergreen bagworm moth, Thyridopteryx ephemeraeformis (Lepidoptera: Psychidae). Annals of the Entomological Society of America 61:38-44.

Kearns, C.A., D.W. Inouye, and N.M. Waser. 1998. Endangered mutualism: The conservation of plant-pollinator interactions. Annual Review of Ecology and Systematics 29:83-112.

Kraemer, M.E., and F.D. Favi. 2005. Flower fidelity and pollen choice of Osmia lignaria (Hymenoptera: Megachilidae) in central Virginia. Environmental Entomology 34:1593-1605.

Lahm, G.P., T.M. Stevenson, T.P. Selby, J.H. Freudenberger, C.M. Dubas, B.H. Smith, D. Cordova, et al. 2007. Rynaxypyr ${ }^{\circ}$ : A new anthranilic diamide insecticide acting at the rynanodine receptor. pp. 111-120. In: H. Ohkawa, H. Miyagawa, and P.W. Lee (Eds.). Pesticide Chemistry, Crop Protection, Public Health, and Environmental Safety. Wiley-VCH, Weinheim, Germany.

Larson, J.L., C.T. Redmond, and D.A. Potter. 2012. Comparative impact of an anthranilic diamide and other insecticidal chemistries on beneficial invertebrates and ecosystem services in turfgrass. Pest Management Science 68:740-748.

Larson, J.L., C.T. Redmond, and D.A. Potter. 2013 Assessing insecticide hazard to bumble bees foraging on flowering weeds in treated lawns. PLOS ONE. 8(6):e66375

Larson J.L., C.T. Redmond, and D.A. Potter. 2014. Impacts of a neonicotinoid, neonicotinoid-pyrethroid premix, and anthranilic diamide insecticide on four species of beneficial insects inhabiting turfgrass. Ecotoxicology 23:252-259.

Mach, B., D. McNamara, and D.A. Potter. 2017. Creating pollinator friendly landscapes. Greenhouse Product News, January. pp. 24-27.

MacIvor, J.S., J.M. Cabral, and L. Packer. 2014. Pollen specialization by solitary bees in an urban landscape. Urban Ecosystems 17:139-147.

Middleton, W. 1922. Sawflies Injurious to Rose Foliage. U.S. Dept. of Agriculture Farmer's Bulletin 1252 of the U.S. Department of Agriculture, Washington, D.C.

Oliver, C.J., S. Softley, S.M. Williamson, P.C. Stevenson, and G.A. Wright. 2015. Pyrethroids and nectar toxins have subtle effects on the motor function, grooming, and wing fanning behavior of honeybees (Apis mellifera). PLOS ONE 10(8):e0133733.

Pisa, L.W., V. Amural-Rogers, L.P. Belzunces, J.M. Bomatin, C.A. Downs, D. Goulson, D. P. Kreutzweiser, et al. 2015. Effects of neonicotinoids and fipronil on non-target invertebrates. Environmental Science and Pollution Research 22:68-102.

Potts, S.G., J.C. Biesmeijer, C. Kremen, P. Neumann, O. Schweiger, and W.E. Kunin. 2010. Global pollinator declines: trends, impacts, and drivers. Trends in Ecology and Evolution 25:345-353.

Qi, S., and J.E. Casida. 2013. Species differences in chlorantraniliprole and flubendiamide insecticide binding sites in the ryanodine receptor. Pesticide Biochemistry and Physiology 107:321-326.

Raupp, M.J., and R.M. Noland. 1984. Implementing plant management programs in residential and institutional settings. Journal of Arboriculture 10:161-169.

Raupp, M.J., J.A. Davidson, J.J. Holmes, and J.L. Hellman. 1985. The concept of key plants for integrated pest management for landscapes. Journal of Arboriculture 11:317-322. 
Reding, M.E., and A.B. Persad. 2009. Systemic insecticides for control of black vine weevil (Coleoptera: Curculionidae) in container- and field-grown nursery crops. Journal of Economic Entomology 102:928-933.

Reding, M.E., and C.M. Ranger. 2011. Systemic insecticides reduce feeding, survival, and fecundity of adult black vine weevils (Coleoptera: Curculionidae) on a variety of ornamental nursery crops. Journal of Economic Entomology 104:405-413.

Rhainds, M., and C. Sadof. 2009. Control of bagworms (Lepidoptera: Psychidae) using contact and soil-applied systemic insecticides. Journal of Economic Entomology 102:1164-1169.

Selby, T.P., G.P. Lahm, and T.M. Stevenson. 2016. A retrospective look at anthranilic diamide insecticides: Discovery and lead optimization to chlorantraniliprole and cyantraniliprole. Pest Management Science. <doi:10.1002/ps.4308>

Selby, T.P., G.P. Lahm, T.M. Stevenson, K.A. Hughes, D. Cordova, I.B. Annan, J.D. Barry, et al. 2013. Discovery of cyantraniliprole, a potent and selective anthranilic diamide ryanodine receptor activator with cross-spectrum insecticidal activity. Bioorganic \& Medicinal Chemistry Letters 23:6341-6345.

Smitley, D., D. Brown, E. Eisner, J.N. Landis, P.M. Shrewsbury, and D.A. Herms. 2016. Protecting and enhancing pollinators in urban landscapes for the U.S. North Central Region. Michigan State University Extension Bulletin E3314.

Szczepaniec, A., and M.J. Raupp. 2013. Direct and indirect effects of imidacloprid on fecundity and abundance of Eurytetranychus buxi (Acari: Tetranychidae) on boxwoods. Experimental and Applied Acarology 59:307-318.

Szczepaniec, A., S.F. Creary, K.L. Laskowski, J.P. Nyrop, and M.J. Raupp. 2011. Neonicotinoid insecticide imidacloprid causes outbreaks of spider mites on elm trees in urban landscapes. PLOS ONE 6(5).

Theiling, K.M., and B.A. Croft. 1988. Pesticide side effects on arthropod natural enemies: A database summary. Agriculture, Ecosystems, Environment 21:191-218.

Tomé, H.V.V., W.F. Barbosa, A.S. Corrêa, L.M. Gontijo, G.F. Martins, and R.N.C. Guedes. 2015. Reduced-risk insecticides in Neotropical stingless bee species: Impact on survival and activity. Annals of Applied Biology 167:186-196.

US-EPA. 2008. United States Environmental Protection Agency Pesticide Fact Sheet: Chlorantraniliprole. <www3.epa.gov/ pesticides/chem_search/reg_actions/registration/fs_PC090100_01-Apr-08.pdf>

Wang, J., Y. Li, Z. Han, Y. Zhu, Z. Xie, J. Wang, Y. Liu, and X. Li. 2012. Molecular characterization of a ryanodine receptor gene in the rice leaffolder, Cnaphalocrocis medinalis (Guenée). PLOS ONE 7(5):e36623.

Whalen, R.A., D.A. Herbert, S. Malone, T.P. Kuhar, C.C. Brewster, and D.D. Reisig. 2016. Effects of diamide insecticides on predators in soybean. Journal of Economic Entomology 109:2014-2019.

Xerces Society. 2013. Pesticide Causes Largest Mass Bumble Bee Death on Record. <www.xerces.org/2013/06/21/pesticidecauses-largest-mass-bumble-bee-death-on-record>

Yu, S.J. 2015. The Toxicology and Biochemistry of Insecticides, second edition. CRC, Boca, Raton, Florida, U.S. 380 pp.

Zhu, Y., C. Zhu, J. Adamczyk, T. Rinderer, J. Yao, R. Danka, R. Luttrell, and J. Gore. 2015. Spray toxicity and risk potential of 42 commonly used formulations of row crop pesticides to adult honey bees (Hymenoptera: Apidae). Journal of Economic Entomology 108:2640-2647.
Carl T. Redmond

University of Kentucky

Lexington, Kentucky 40546-0091, U.S.

Daniel A. Potter (corresponding author)

S-225 Agriculture Science Bldg. N.

University of Kentucky

Lexington, Kentucky 40546-0091, U.S.

E-mail:dapotter@uky.edu

tel: $1-859-257-7458$

fax: 859-323-1120

Résumé. Les professionnels de l'horticulture ont besoin d'insecticides sélectifs afin de gérer les insectes nuisibles des plantes ornementales ligneuses susceptibles d'être visités par les abeilles et les autres insectes pollinisateurs. Le chlorantraniliprole, premier insecticide diamide anthranilique homologué pour usage en milieu urbain, cible de façon sélective les récepteurs qui régulent le flux de calcium qui commande la contraction musculaire chez les chenilles, les coléoptères et certains autres insectes phytophages. Identifié en tant que pesticide à risque réduit par l'Agence américaine de protection de l'environnement (EPA), il a un profil toxicologique et environnemental favorable, démontrant une très faible toxicité pour les abeilles et la plupart des insectes prédateurs et parasitaires qui contribuent à la suppression des organismes nuisibles. Le chlorantraniliprole est devenu un pilier de la gestion des ravageurs de pelouses, mais il existe peu de publications faisant état de sa performance contre les organismes nuisibles des plantes ornementales ligneuses. Les chercheurs l'ont évalué contre les ravageurs couvrant cinq ordres d'insectes différents: les scarabées japonais adultes, la chenille burcicole, la livrée d'Amérique, la squeletteuse du rosier, la punaise de l'aubépine, le puceron du laurier rose, le psylle de buis, la cochenille du chêne et la mineuse du buis, en utilisant des situations réelles d'exposition. L'efficacité du chlorantraniliprole, la rapidité du contrôle et l'activité résiduelle suite à des pulvérisations foliaires contre des insectes broyeurs de feuilles étaient aussi bonnes sinon meilleures que celles prétendues par les normes de l'industrie cependant, les pulvérisations se sont avérées inefficaces contre les insectes suceurs (punaises, pucerons et cochenilles). Des trempages effectués au pied du tronc à l'automne ou au printemps ont échoué à contrôler systémiquement les psylles ou les mineuses du buis, mais les trempages d'automne ont éliminé les dégâts de la squeletteuse du rosier et les dommages du scarabée japonais, l'année suivant le traitement. Cette étude indique que le chlorantraniliprole peut être une composante efficace des programmes intégrés de lutte contre les ravageurs et les pollinisateurs pour les plantes ornementales ligneuses.

Zusammenfassung. Landschaftsprofis brauchen selektiv wirkende Insektizide, um Schädlinge auf blühenden Büschen und Sträuchern zu kontrollieren, die auch von Bienen und anderen befruchtenden Insekten besucht werden können. Chlorantraniliprol, das erste für den Einsatz in urbanen Lanschaften registrierte Anthranildiamid-Insectizid, zielt selektiv auf die Rezeptoren, die den Fluss von Kalzium zur Kontrolle der Muskelkontraktion bei Raupen, Pflanzen fressenden Käfern und bestimmten anderen phytophagen Insekten regulieren. Verabschiedet von der United States Environmental Protection Agency (Umweltschutzbehörde) als ein Pestizid mit vermindertem Risiko, hat es ein zu bevorzugendes toxikologisches und ökologisches Profil, einschließlich einer sehr geringen Toxizität gegenüber Bienen und vielen Typen von Raubund parasitischen Insekten, die zur Unterdrückung von Schädlingen beitragen. Chlorantraniliprol wurde eine Hauptstütze für die Schädlingskontrolle bei Gräsern, aber es wurde bislang wenig 
darüber veröffentlicht, wie seine Leistungen bei holzigen Pflanzen wirken. Die Forscher bewerteten es im Einsatz bei Schädlingen aus fünf verschiedenen Ordnungen: adulte Japankäfer, immergrüne Sackwürmer, östliche Zeltraupe, Sägewespen, Lackkäfer, OleanderLäuse, Buchsbaumpsylliden, Eichenschildläuse und Buchsbaumblattbohrer, indem lebensechte Szenarios simuliert wurden. Die Effizienz von Chlorantraniliprol, die Geschwindigkeit der Wirkung und die Restaktivität als Blattspray im Einsatz bei blattfressenden Schädlingen war gut oder besser als die Industriestandarts, aber die Sprays waren ineffektiv gegen saugende Schädlinge (Lackkäfer, Läuse oder Schildläuse). Basale Bodenapplikationen im Herbst oder Frühling versagten bei der Kontrolle von Buchsbaumpsylliden oder Buchsbaum-Blattbohrern, aber Herbst-Applikationen konnten die Schäden durch Rosenblattwespen und im Frühjahr fressende Japankäfer unterdrücken. Diese Studie zeigt, dass Chlorantraniliprol eine effektive Komponente in Integrierten Pflanzenschutzprogrammen bei holzigen Pflanzen sein kann.

Resumen. Los profesionales del paisaje necesitan insecticidas selectivos para el manejo de plagas de insectos en plantas ornamentales leñosas que pueden ser visitadas por las abejas y otros insectos polinizadores. El clorantraniliprole, el primer insecticida de diamida antranilico registrado para uso en paisajes urbanos, se dirige selectivamente a los receptores que regulan el flujo de calcio para controlar la contracción muscular de las orugas, los escarabajos de la alimentación vegetal y ciertos otros insectos fitófagos. Designado plaguicida de riesgo reducido por la Agencia de Protección Ambiental de los Estados Unidos, tiene un perfil toxicológico y ambiental favorable, incluyendo muy baja toxicidad para las abejas y la mayoría de los tipos de insectos predadores y parasitarios que contribuyen a la supresión de plagas. El clorantraniliprole se ha convertido en un pilar para la gestión de las plagas de césped, pero poco se ha publicado sobre su rendimiento contra las plagas de plantas ornamentales leñosas. Los investigadores la evaluaron contra plagas que abarcaban cinco órdenes diferentes: escarabajos japoneses adultos, gusano de hoja perenne, oruga oriental de la tienda, mosquitero erizo de rosas amarillas, insecto de encaje de espino, áfido de adelfa, psyllid de boj, escama de lecanio de roble escenarios de exposición. La eficacia del clorantraniliprole, la velocidad de control y la actividad residual como pulverización foliar para las plagas masticadoras de hojas fue tan buena o mejor que la proporcionada por los estándares de la industria, pero los pulverizadores eran ineficaces contra las plagas de succión (encajes, áfidos o escamas). Los drenajes basales del suelo en otoño o primavera fallaron en controlar sistemáticamente los psílidos o minadores de hojas, pero los brotes de otoño suprimieron el daño causado por los rosas y la alimentación del escarabajo japonés al año siguiente. Este estudio indica que el clorantraniliprole puede ser un componente efectivo de los programas integrados de manejo de plagas y polinizadores en plantas ornamentales leñosas. 